\title{
Rewindykacje pustki, czyli prawie wszystko o prawie niczym
}

Piotr Michałowski

TEKSTY DRUGIE 2018, NR 1, S. 231-239

DOI: $10.18318 /$ td.2018.1.13

O pustce można nieskończenie, choć to nie gadanie o niczym, którego czas zależy od krasomówczej inwencji i wydolności krtani. Rozważanie Pustki pisanej wielką literą lub minuskułowej, czyli braku czegoś określonego, rozszczepia się bowiem na odrębne dyskursy różnych dyscyplin badawczych, mnogość koncepcji, ujęć i sekwencji przykładów; tworząc deltę dowolności. Niemniej wolno wierzyć w istnienie jakiejś kanonicznej egzemplifikacji, skompilowanej z odkryć stalkerów fizyki, filozofii, etnologii i sztuki. Ich ekspedycje wiodą wprawdzie w obszary odmienne, pozwalając zapomnieć o wspólnocie humanistki, w której specjalizacja doprowadziła do schizmy metodologicznej, mnożącej alternatywne metakonceptualizacje rozmaicie konceptualizowanych pustek.

Zajmująca książka Małgorzaty Czapigi jest przeglądem pustek dziwnie selektywnym, a nawet przygodnym. Zapewne, jeśli lektura pozostawia niedosyt, to wskutek nadmiernych oczekiwań zapowiedzianych w tytule: $P_{0-}$ -widoki pustki, a zwłaszcza w bardziej zobowiązującym

\section{Piotr Michałowski - dr hab., kierownik Zakładu Teorii i An- tropologii Literatury Uniwersytetu Szcze- cińskiego. Ostatnio opublikował m.in. książki: Mikrokosmos wiersza. Interpretacje poezji współczesnej (2012) i Znarożnika mapy (2017) oraz zredagował tom zbiorowy Od pióra do sieci.Zmienne media literatury (2015).}


podtytule: O sposobach konceptualizowania pustki w kulturze wspótczesnej'. Badania obejmują głównie pustkę empiryczną, czyli po czymś, wynikającą z braku jakiegoś wypełnienia; natomiast niewiele uwag dodanych na marginesie tak ukierunkowanych rozważań dotyczy Pustki absolutnej, pozostającej w sferze spekulacji logiczno-ontologicznych oraz skrajnych doświadczeń awangardy artystycznej. Za horyzontem znika więc „próżnia doskonała”, notabene odsyłająca choćby do twórczości Lema, który zostaje przywołany raz tylko, i to w cytacie z pracy Slavoja Žižka o Andrieju Tarkowskim. A właśnie ona mogłaby dostarczyć przykładów najciekawszych, by wspomnieć choćby bajkę Jak ocalał świat, w której maszyna, wąsko wyspecjalizowana w robieniu wszystkiego na literę „n”, na życzenie nierozważnego Klapaucjusza robi wielkie „Nic”, zmierzając do anihilacji Wszechświata. Nie wspomina się nawet o sztuce konceptualnej, a wypadałoby to uczynić, choćby z uwagi na związek etymologiczny $\mathrm{z}$ hasłem użytym w podtytule.

Trzeba się zgodzić na selektywny ogląd zjawisk, uznając, że koncepcji pustki jest tyle, ilu „pustkologów” (łacińska „inanisologia” brzmi nie lepiej niż angielska „emptynessology"). Autorka zawęża zakres badań najpierw do tekstów kultury z pustką „uwidocznioną” i wprowadza kategorię „po-widoku”, będącego materialną reprezentacją lub substytutem „pustki” - w odróżnieniu od optycznego „powidoku”, adaptowanego do malarstwa przez Teorię widzenia i praktykę malarską Władysława Strzemińskiego. Następnie zawęża horyzont do kultury Zachodu (choć, jak się okaże, zaliczy do niej przedemigracyjną twórczość filmową Tarkowskiego), wreszcie - do sztuk wizualnych, powołując się na niedawny „zwrot ikoniczny”. Ambiwalencja przykładów z historii kultury nie wydaje się mocnym argumentem na XX-wieczny iconic turn albo pictorial turn. Dygresje o utrudniającym komunikację kulturową rozpadzie kanonu, standaryzacji nauki i karaoke są wprawdzie doniosłe, ale zbyt odległe; natomiast istotna i trafna wydaje się „po-widokowa” diagnoza kultury postmodernistycznej, choć ten zwietrzały już przymiotnik nie zostaje użyty:

Wydaje się, że kultura współczesna też w dużym stopniu ma charakter po-widokowy. Użytkownik/współtwórca konfrontuje się nieustannie z tekstami różnego rodzaju, zapamiętując je - w mniej lub bardziej świadomy i aktywny sposób - aby zaraz odwrócić od nich swoją uwagę i penetrować kolejne kadry kultury. W trakcie tej percepcji pozostają w nim jednak

1 M. Czapiga Po-widoki pustki. O sposobach konceptualizowania pustki w kulturze współczesnej, Universitas, Kraków 2017. 
po-widoki poprzednich, obrazy następcze, ulegające często zniekształceniom, nawarstwieniu, zdekontekstualizowaniu. (s. 33-34)

Z jednej strony autorka przywołuje badania Aby Warburga nad „pamięcią obrazu” jako „pamięcią kultury”; z drugiej - ujmuje „po-widok” jako zjawisko, które „nie odsyła do żadnego obrazu poprzedzającego, choć egzystuje wobec jego kształtu, to nie generuje już sytuacji dialogowej" (s. 34). W miarę jak rozrasta się ta egzegeza, wspierana erudycyjnie pracami Bal, Beltinga, Benjamina, Bergsona, Leśniaka i Lipińskiego, słabnie wartość wprowadzonej metafory, aż wydaje się ona zbędna - jako synonim „cytatu”. A przecież dekonstrukcja oferowała kategorię „śladu” (przywołane tu mimochodem i w innym znaczeniu), która również wydaje się bliskoznaczna i warta skonfrontowania z „powi-dokiem” w celu ustalenia związków i zakresów obu metafor. Zrozumiałe, że przyjęta w śledzeniu pustek perspektywa wizualna narzuca odwołania do słynnej teorii „symulakrów”, toteż Baudrillard staje się przypisem tyleż nieuniknionym, co natrętnym; natomiast niepokoi to, że pantekstualizm z Derridą nie pojawiają się ani razu, choć dyskurs ociera się o zjawiska podobne. Czyżby perspektywa „kultury jako obrazu” wykluczała inspirację teoriami "kultury jako tekstu” - o której autorka zresztą wspomina, ale tylko po to, by ją odrzucić? Wynalazczość w zakresie metafor poznawczych czy quasi-terminologii mimowolnie dowodzi tezy o zaniku świadomości kontekstów u badaczki, gdyż właśnie wynalazek „po-widoku” przypomina lampę naftową wstawioną do pracowni Edisona, dawno już oświetlonej żarówką.

W rozdziale drugim Spacial turn i kategoria pustki czytamy o „zwrocie przestrzennym" w myśleniu o kulturze i wyparciu diachronii przez synchronię. Autorka jakby nie zauważa, że inne „zwroty” w humanistyce tę zmianę neutralizują, niekiedy jej przeczą, a czasem rekompensują; ale cóż począć, jeśli właśnie wybrany „zwrot” najlepiej nadaje się do spożycia w kontekście omawianych zjawisk? Seryjne obwieszczanie „zwrotów” powinno skłaniać do krytycznego dystansu; a tymczasem badaczka bezrefleksyjnie przyjmuje obowiązującą chronologię spacial turn, którą można łatwo zrewidować, sięgając do bibliografii. Otóż, pisząc rozprawę magisterską ze spacjologii w roku 1982, korzystałem m.in. ze znakomitej pracy zbiorowej Przestrzeń i literatu$r a^{2}$, o której tu nawet nie wspomniano, co niestety potwierdza powszechną pogardę dla dokonań teorii rodzimej, nawet jeśli ona wyprzedza koncepcje zagraniczne. Wobec takiej praktyki nie dziwi już to, że dawno oswojone

2 Przestrzeń i literatura, red. M. Głowiński, A. Okopień-Sławińska, Ossolineum, Wrocław 1978. 
kategorie powracają teraz jako egzotyczne odkrycia i trzeba się powołać na pracę Yi-Fu Tuana z 1987 roku po to, by odróżnić „przestrzeń” od „miejsca”. Lawinowo przyrastające "turny” i coraz liczniejsze wystąpienie "turnerów” łudzą nowością, lekceważąc wcześniejsze źródła i rzeczywistych założycieli, nie mówiąc o prekursorach - zresztą takich jak nomen omen William Turner, malarz romantyczny, który o trzydziestolecie wyprzedził impresjonizm (choć „turner" to tylko angielski „tokarz”). Entuzjazm wobec nowości nie zwalnia z rzetelnego wglądu w dziedzictwo kultury.

Omawiane tu "opowieści” o po-widokach pustki są opartymi na pamięci (indywidualnej lub społecznej) próbami „wizualnego wykroczenia”, czyli przedstawienia niewidzialnego jako widzialne. Innymi słowy: chodzi o szczególny status wizualizacji (nie wiedzieć czemu i ten termin został pominięty) - zarówno minionego konkretu, jak i uniwersalnej abstrakcji. Tytuły podrozdziałów naprowadzają na jakąś typologię „pustek”, niestety zaniechaną, choć implicite wyłania się jej ogólny zarys: pustka przed, pustka po i pustka zamiast. Podrozdział Pustka początku opowiada o prakosmicznym chaosie, a raczej o jego wyobrażeniach w mitologiach i Księdze Rodzaju. Następuje przydługi cytat z kabalistycznego wywodu Chaima Vitala, w przyciężkim przekładzie (zresztą bez podania tłumacza), który wydaje się egzemplifikacją słabo uzasadniona. Lepszym przykładem paradoksalnej kreacji ex nihilo byłby pochodzący z około 1500 roku p.n.e. Hymn o początkach wszechrzeczy z Rigwedy.

Kolejne podrozdziały to: Pusty orbis exterior, Inicjacja w pustce, Mistyczna pustka „odosobnienia” i Kosmiczna pustka. Badaczka przytacza pogląd Kołakowskiego, że strukturalistyczny umysł ludzki nawykł do postrzegania opozycji, zatem każdą rzecz rozpoznaje na tle świata, który nie istnieje: omnis determinatio est negatio. Tu warto byłoby rozwinąć właśnie wątek logiczno-epistemologiczny, a przynajmniej wspomnieć o poetyce negatywnej. Tymczasem, porzucając ten ciekawy trop, autorka zadowala się stwierdzeniem, że empiria przeczy istnieniu pustki absolutnej. Otrzymujemy więc serię przykładów - interesujących w szczegółach, natomiast w ogólnych założeniach dość oczywistych: biblijny motyw anachoresis (odosobnienia na pustkowiu w celu zbliżenia się do Boga, oczyszczenia, kontemplacji, przemiany, transgresji), „próby pustyni" eremitów, asceza Mistrza Eckharta i św. Jana od Krzyża... Ciekawsze są przykłady pustki w architekturze sakralnej i w przestrzennej aranżacji berlińskiego muzeum Holokaustu. Kończący Część I rozdział Abstrakcje i konkrety pustki jest krótkim uchyleniem okna na rozleglejsze pola badań zaniechanych. Znajdziemy wprawdzie cytaty o konwencjonalności przedstawienia pustki, ale trop lingwistyczny urywa się na kwestiach etymologii i frazeologii. 
Cytowany Ryszard Nazar wskazuje na pochodzenie wyrazu „nicość” od zaprzeczenia: „nie coś”. W poezji zwrócił na to uwagę m.in. (nawet niewspomniany) Ryszard Krynicki.

W trzykrotnie dłuższej Części II Studia przypadków, obejmującej rozwinięcia kilku wątków z wcześniejszego rekonesansu, można oczekiwać przykładów najciekawszych, a więc skrajnych, choć niekoniecznie „reprezentatywnych", jeśli takie w ogóle istnieją w sferze pustki. Zdarzają się powtórzenia, niekiedy tych samych cytatów, zapewne wskutek nieuwagi w redagowaniu całości, zintegrowanej z odrębnych artykułów.

Rozdział Mity, toposy i metafory obszernie omawia motyw łąki jako krainy przejściowej między naturą a kulturą, bo półdzikiej a półoswojonej, która ponadto reprezentuje zaświaty i przedsionek raju. Dalej następują dygresje etnologiczne o zielarstwie i ludowej fitoterapii, skądinąd ciekawe, lecz „z innej bajki”. Drugim przykładem z tego samego pogranicza jest „rewanż dziejowy”, przywracający naturze przestrzeń zagarniętą przez kulturę: ruiny, będące według Waltera Benjamina alegorią historii. Ich współczesny fenomen badaczka wyjaskrawia, powołując się na eseje Georga Simmela:

Pustka związana z ruiną ujawnia się tym, że nie ma tego, co było, ale ruina świadczy jeszcze o tym, co było, przez to, co pozostało. (s. 93)

Niezręczność stylistyczna tej egzegezy (może „po białoszewsku” celowa) najlepiej wyostrza paradoksalny status obiektu zniszczonego w przestrzeni miejskiej - jako po-widoku przeszłości; ale zarazem relatywizuje status pustki, która przecież w tym wypadku już nią nie jest, ponieważ istnienia całkowicie nie zastępuje, lecz jest jego synekdochą - i szkoda, że nazwa tej figury nigdzie się nie pojawia. Ruina stanowi dopiero namiastkę zarówno bytu, jak i niebytu, a więc pozostaje - jakkolwiek paradoksalnie to zabrzmi pustką połowiczną.

Kolejnym przykładem są akwaforty Piranesiego jako źródło romantycznej fascynacji ruinami, ale najobszerniej omówiony cykl Carceri d'Invenzione, przedstawia więzienia nieistniejące i prawie niezaludnione. W pewnym stopniu, co zauważa autorka, można je czytać jako topos świata-więzienia, o którym wspomniał Hamlet, zawężając odniesienie do Danii. Wywód skupia się jednak na obrazach więzień słabo zaludnionych, zdumiewających dysproporcją ogromu budowli z nikłością postaci ludzkich. W uwagach o dysproporcjach zabrakło odniesień do Swifta, który ten motyw rozwinął najlepiej, natomiast w interpretacji semantyczno-etycznej grafik nasuwa się 
dopowiedzenie, które zaburza przyjętą wykładnię ikonologiczną; otóż zgodnie z logiką motyw pustego więzienia zawiera przesłanie pozytywne. Piranesi budzi więc wątpliwości jako egzemplifikacja pustki, podobnie jak literackie inspiracje jego dziełami u Poego, Kafki czy Borgesa oraz w filmowym ekspresjonizmie Fritza Langa. Pustka zyskuje konotacje ściśle ludzkie, odsyłając raczej do innych pojęć: samotności, wyobcowania, nadmiaru, nieskończoności, labiryntu i piekła - wyobrażeń słabo przystających do kategorii „po-widoku”. Szlak ekspedycji badawczej zwodzi więc na manowce sensów zbyt odległych.

Celne przykłady znajdziemy natomiast w rozdziale Historia i melancholia, gdzie zamiast imaginarium pojawia się empiria „niemiejsca”. Na tym terenie badaczka służy za znakomitą przewodniczkę. Chodzi o dwie sytuacje wyludnienia przestrzeni: po katrastrofie i po Holokauście. Wprowadzeniem są uwagi o redukcji przestrzeni w świadomości współczesnego podróżnika wskutek globalizacji kulturowej i wirtualizacji obrazu świata.

Wartościowa wydaje się zwłaszcza faktografia dotycząca Czarnobyla, miejsca zwanego "Zoną” i funkcjonującej tam „turystyki katastroficznej”. Czytamy także o polskich terenach opuszczonych przez armię radziecką i amerykańskich ghost towns - miastach wyludnionych po gorączce złota ${ }^{3}$. Innym wątkiem jest problem „zwijania przestrzeni” w odniesieniu do Shoah. Chodzi tu przede wszystkim o granice wyrażalności i metody dokumentacji Zagłady. Pośród przykładów paradoksalnych autorka wskazuje 9,5-godzinny film Claude'a Lanzmanna, w którym zdjęcia archiwalne zostają całkowicie zastąpione obrazem współczesnej pustki po obozie.

Dwa przykłady w rozdziale następnym Pustkowie: filmowy krajobraz zmityzowany stanowią świetne dopełnienie rozważań fenomenów zarówno miejsc opuszczonych, jak i ich wizualnych reprezentacji. Podrozdział Andriej Tarkowski czytany przez mit Czernobyla skupia się na motywie stalkera - przewodnika wypraw badawczych i turystyki katastroficznej do Zony, która staje się miejscem zarówno przeklętym, jak i świętym, a nawet symbolem Absolutu. Autorka przypomina genezę motywu i chronologię jego wędrówki, która ostatecznie zawiodła do kultury masowej: narodził się w powieści Arkadija i Borisa Strugackich Piknik na skraju drogi (1972), która stała się inspiracją dla

3 Wydaje się, ze zabrakło tu przykładu geograficznie najbliższego, może dlatego, że jest oczywistością. Domyślnym suplementem byłoby wskazanie pustki najbardziej spektakularnej w dziejach Europy: zniszczenia Warszawy po powstaniu w 1944 roku, a także fenomen współczesnych kontrowersyjnych wyburzeń w stolicy, które dotknęły budynki powojenne, w tym nawet wzniesione w latach 9o. Jako źródło wskazać można choćby album Ł. Gorczycy i M. Kaczyńskiego Ruiny Warszawy (Raster, Warszawa 2016). 
filmu Tarkowskiego Stalker (1979), następnie został skojarzony z prawdziwą historią Czarnobyla (1986), która niejako potwierdziła te fantastyczne fikcje, aż w końcu trafił do gier komputerowych (2003). Z kolei film Wernera Herzoga Spotkania na krańcach świata jest oryginalną formą prezentacji pustki na lądzie i w podwodnym świecie Antarktyki - co płynnie wprowadza w kolejne zagadnienie: pustki w kartografii.

Końcowy rozdział wypełniają dwa ciekawe materiałowo artykuły o mapie - jej istocie, historii i współczesnych transformacjach. W ostatnim dziesięcioleciu fenomenem kartografii zainteresowały się socjologia, semiotyka i antropologia; jednak nie ma potrzeby obwieszczania odrębnego „zwrotu kartograficznego". Pierwsze znane mapy pochodzą z około 2300 roku p.n.e, z Babilonii i Egiptu, ale badania archeologiczne mogą jeszcze cofnąć datację o stulecia i odkryć inne miejsca narodzin. Od początku mapa łączyła dokumentację wiedzy o świecie z wyobrażeniem o dalszych lądach i morzach, stanowiąc w różnych proporcjach efekt poznania i narzędzie perswazji. Mapy szybko się dezaktualizują, zawsze jednak pozostają świadectwem tyleż trwania, co przemijania. Inspirują pisarzy, czego dowodzi imponujące bogactwo przykładów z literatur kilku obszarów językowych: Andrzeja Stasiuka, Jacka Dehnela, Czesława Miłosza, Itala Calvina, Michela Houellebecqa, a najciekawszym wydaje się książka Judith Schalansky Atlas wysp odlegtych, której omówienie wypełnia osobny podrozdział.

Zdobycze techniczne, takie jak GPS, internetowe mapy interaktywne, wreszcie gry komputerowe, pozwalają uprawiać turystykę wirtualną ze złudzeniem nieograniczonego dostępu i wolności wyboru, ale w jakimś stopniu determinują trasy podróży i ukierunkowują decyzje flâneura, niekiedy przeobrażonego w voyeurystę. Konstatacja ograniczeń studzi entuzjazm techniczny, który zapłonął zaledwie stronę wcześniej w optymistycznej diagnozie, że na dzisiejszych (zwłaszcza wirtualnych) mapach nie ma już białych plam. Otóż białe plamy, choć może się kurczą lub przemieszczają, będą istnieć tak długo, jak dystrybucją informacji i wiedzy o świecie rządzą polityka i ekonomia. Badaczka, nie dostrzegając gry interesów w kształtowaniu map, wskazuje natomiast kuriozalne przykłady cenzury z czasów odkryć geograficznych, kiedy to zazdrośnie strzeżono istnienia pewnych cennych złóż i skarbów, obejmując je klauzulą tajności, zwaną „ciszą kartograficzną”.

Oczywiście niemożliwa byłaby monografia całej rozległej tematyki pustki na 230 stronach (dalej zaczyna się długa bibliografia i niestety zbyt krótki indeks nazwisk). Niemniej trudno pogodzić się z doborem przykładów - dość kapryśnym, zwłaszcza w odniesieniu do sztuki współczesnej. Książka nie tyle 
zaprasza do glosowania, ile wręcz prowokuje do wytknięcia poważnych przeoczeń. Status pominięć jest niejednakowy, toteż warto upomnieć się jedynie o ważniejsze z nich, a i tak brakujące "pustki” ukażą skandaliczny stan rzeczy, bliski opisowi nocnego Krakowa w piosence Turnaua Cichosza. W muzyce: nie ma Johna Cage'a z jego słynnym (choć nie „głośnym”, bo wypełnionym ciszą) utworem 433 z 1952 roku. W plastyce, mimo pictorial turn i deklarowanej preferencji sztuk wizualnych, nie pojawia się Kazimierz Malewicz z Czarnym kwadratem na biatym tle (1915). Niekiedy na oczywiste skojarzenia z tytułowym przedmiotem badań naprowadzają (niestety bez skutku) same tytuły - jak choćby słynnego manifestu teatralnego Petera Brooka Pusta przestrzeñ ${ }^{4}$, w którym pośród wyodrębnionych czterech typów teatru reżyser wymienia „Teatr Święty", Artauda i Grotowskiego, zakładający dotarcie do niewidzialnego i niewyrażalnej strefy znaczeń.

Najdotkliwsze są pominięcia literackich konceptualizacji pustki, choć autorka przyjmuje perspektywę kulturoznawczą w takiej odmianie, w której "zwrot kulturowy" nie oznacza całkowitego odwrotu od literatury. Niestety, sztuka słowa w jej widnokręgu refleksji nie służy za równoprawny rezerwuar przykładów autonomicznej kreacji artystycznej, lecz staje się źródłem pośrednim etnologii, paradokumentem wierzeń ludowych. Nie ma zatem ani Laurence'a Sterne'a z jego wizualizacjami pustki w Tristramie Shandym, ani podobnych eksperymentów Edwarda Stachury, ani Brunona Jasieńskiego jako autora (choć właśnie status autorstwa budzi tu wątpliwości) wiersza (lub prozy?) pt. Nic. Leśmian zostaje wspomniany epizodycznie i tylko w kontekście „znakomicie przedstawionych stanów uniesienia erotycznego". Przyboś pojawia się jedynie jako komentator malarstwa Strzemińskiego i autor antologii poezji ludowej Jabłoneczka. Pominięcie jego dorobku poetyckiego, który refleksję o pustce mógłby wyprowadzić w szersze horyzonty, jest bolesną rezygnacją (bo chyba nie przeoczeniem?). Brak choćby wzmianki o najlepiej w poezji wyrażonym dramacie pamięci konfrontowanej z bieżącym doświadczeniem i bezpośrednim doznaniem; a nawet jeśli aspekty „po-widokowe” liryki Przybosia zostały uznane za nieinteresujące jako sztuka niewizualna, to przecież pozostaje ich ścisła korespondencja z Teoria widzenia Strzemińskiego czy choćby psychologiczna analiza samego mechanizmu percepcji wzrokowej i pamięci. Poza tym nie ma w ogóle Różewicza, a spośród licznych przykładów, które mogłaby dostarczyć Szymborska, znalazła się jedynie jej

4 P. Brook Pusta przestrzeń, przeł. W. Kalinowski, Wydawnictwa Artystyczne i Filmowe, Warszawa 1977. 
poetycka refleksja o mapie, zresztą w kontekście świetnych rozważań nad kartografią. Pojawia się wprawdzie zdanie: „najpiękniejszy jest przedmiot, którego nie ma", ale bez podania źródła, toteż Zbigniew Herbert zasila zastęp wielkich nieobecnych, zresztą solidarnie z Malewiczem. „To wszystko nazywa się nic?" - chciałoby się na koniec tego wyliczenia braków zapytać cytatem z Brzechwy, ale nie wypada cytować wiersza o leniu.

Co gorsza, zabrakło refleksji estetycznej, sięgającej do głębszych kontekstów epistemologii, a główne miejsce na mojej wirtualnej liście nieobecności zajmuje Roman Ingarden i jego „miejsca niedookreślenia” - brak to dziwny w humanistycznym dyskursie o pustce i „po-widokach”, których skojarzenie z procesem czytelniczej konkretyzacji powinno się wręcz narzucać. Spuentuję oksymoronem: rozważanie pustki bez tych ekspertów od nicości zawsze będzie niepełne.

\section{Abstract}

\section{Piotr Michałowski}

UNIVERSITY OF SZCZECIN

Reclaiming Emptiness, or: Almost Everything about Next to Nothing

Review: M. Czapiga, Po-widoki pustki. O sposobach konceptualizowania pustki w kulturze współczesnej [After-Images of Emptiness: Conceptualizing Emptiness in Contemporary Culture] (Cracow: Universitas, 2017).

\section{Keywords}

ethnology, anthropology, literary studies, twentieth-century literature, history of twentieth-century art, architecture, emptiness, nothingness, iconic turn, pictorial turn, spacial turn 